\title{
Development of Vegetable Seeds Incorporated Cookies: Nutrient Composition, Functional Properties, Mineral Analysis and Sensory Evaluation
}

\author{
Ms. Mani Sahai \\ B.Sc. Home Science (Honours), University of Delhi \\ M.Sc. (Food Science \& Nutrition), Diploma in Food Processing, Banasthali Vidyapith, Rajasthan, India
}

\begin{abstract}
Jackfruit and Okra are popular fruit crops grown in India. The seeds are the by-product obtained during the processing of these crops. Jackfruit seed possess disposal problem if not handled properly. Scientific data shows that jackfruit and okra seed powder has various health benefits like prevent cancer, lowers the risk of heart disease, improves digestive system, boost immunity in the body, maintains blood glucose levels and helps to increase bone mineral density. The seeds of these crops are particularly a rich source of proteins, starch, minerals and dietary fibres along with phytonutrients. The present study was designed to investigate proximate composition, functional properties and mineral analysis of the best composite flour. Randomization of variables were done along with their nutrient composition. The flour having the highest nutritional value was selected as the best composite flour. Sensory evaluation of the developed food product by incorporating Okra seed flour, Jackfruit seed flour and Wheat flour was also done. After that physical properties of the most acceptable food product were carried out. Results for proximate composition revealed that jackfruit seed flour had an appreciable amount of moisture and protein i.e. 9.08 \pm 0.6 and $5.12 \pm 0.43$ and low amount of fat i.e. 3.6 \pm 0.3 . While okra seed flour possesses a high amount of moisture and ash i.e. $6.7 \pm 0.07$ and $6.61 \pm 0.4$. Estimation of functional properties revealed that water absorption capacity i.e. $1.68 \pm 0.051$ and oil absorption capacity i.e. $1.81 \pm 0.057$ of the composite flour was high but the bulk density $0.95 \pm 0.02$ was very low. Mineral analysis depicted the presence of higher amount of calcium i.e. 3.49 \pm 0.02 and iron i.e. $2.71 \pm 0.01$ but low amount of potassium i.e. $1.46 \pm 0.02$ in the best composite flour. Sensory evaluation of the product developed (Cookies) was carried out using 9-point hedonic scale with various attributes in four concentrations i.e. $5 \%, 10 \%, 15 \%$ and $20 \%$ and were compared with the standard. Sensory evaluation revealed that up to the level of $5 \%$ the developed products were more acceptable than
\end{abstract}

standard. The physical properties with 5\% level of incorporation were carried out. Results depicted that oil absorption capacity was high i.e. $4.88 \pm 0.02$ and good amount in dispersibility i.e. $4.01 \pm 0.01$ water absorption capacity i.e. $3.74 \pm 0.01$ but low amount of percent solubility i.e. 1.66 \pm 0.01 . Thus, the results signify that okra and jackfruits seeds are a good source of various nutrients, functional and mineral properties.

Keywords- Jackfruit seed flour, Okra seed flour,Byproduct, Phytonutrients, Standardization of flour, Functional properties.

\section{INTRODUCTION}

Fruit and vegetable processing has increased considerably during the last 25 years (Indraniet al, 1997). This has reflected the increase in demand for pre-processed and packaged food, particularly ready meals. During the period, many modern processes were developed and implemented but disposal of waste was not the major issue it is today. Competitive advantage was often achieved by exploiting the benefits of economies of scale, and strategies consequently involved the centralization of processing activities. This resulted in localized production of large tonnages of waste co-products. These were often disposed of relatively cheaply by landfill, land spreading or selling as animal feed or for its production. The issue of waste in our modern society has become more prominent since it contributes too many of the problems of global environmental sustainability (Claughtonet al, 1989). Vast quantities of food processing co-product wastes are produced throughout the world.

For most fruits and vegetables, one can estimate the likely waste as approximately $30 \%$ or more of processed material or even in some processes; it may be up to $75 \%$ (Sathe et $a l, 1982$ ). Nowadays, the high volume of waste produced marks food industry. According to the recent research conducted by FAO, about 1.3 billion tons of food has been wasted worldwide per year, which represents one third of 
the total food industry production (FAO, 2009). The largest amount of loss is verified by fruits and vegetables, representing 0.5 billion tons. In developing countries, fruit and vegetable losses are severe at the agricultural stage but are mainly explained by the processing step, which accounts for $25 \%$ of losses. The growing, processing and preparation of fruit and vegetables result in the production of varying degree of waste material. The waste material may be in the form of leaf, straw and seeds waste during harvesting, processing industry waste and after processing waste (Devraj et al, 2008). The waste obtained from fruit processing industry is extremely diverse due to the use of wide variety of fruits and vegetables, the broad range of processes and the multiplicity of the product (William et al, 1987).

The by-product seeds represent an important source of sugars, minerals, organic acid, dietary fibre and phenolics, which have a wide range of action, which includes antiviral, antibacterial, cardio-protective and antimutagenic activities (Kumar et al, 1988). Because of increasing threat of infectious diseases, the need of the hour is to find natural agents with novel mechanism of action. Natural products provide unlimited opportunities for new drug leads because of the unmatched availability of chemical diversity. Fruit and vegetable seeds are thrown into the environment as agro waste which can be utilized as a source of anti-microbes (Bremneret al, 1996). However, there is currently no major exploitation of these sources, due to the poor understanding of their nutritional and economic value, adding that there is a great opportunity for agribusiness in the area. (Jain et al, 2008). Utilization of those by-products as a valuable source of natural food additives appears to be a good alternative toward mitigation of environmental problems and for further exploitation of food additives or supplements having high nutritional value and economically attractive. The transformation of these by products into a "product" with high added value makes it possible for the companies to reduce their cost of treatment, and even to generate additional profits, and thus to improve their competitiveness (Bobbioet al, 1978).

The antioxidant capacity of seed is high. Carotenoids are phytochemicals presented in considerable amount in fruit tissue (Rufino et al, 2010). Carotenoids play a potentially important role in human health by acting as biological antioxidants, protecting cells and tissues from the damaging effects of free radicals and singlet oxygen and are used as natural colorants in the food industry (Singh et $a l, 2001)$. The characteristic feature of some tropical exotic fruit by-products like jackfruit seeds is that it has high contents of soluble dietary fibre, which is reported to have more health beneficial effects. The waste generated during the processing of passion fruit mainly consists of peel and seeds.
Despite the high content of bioactive compounds in the skins and seeds of exotic fruits, attention must be paid to antinutritional and toxic factors, like high tannin content in these tissues (Abdalla et al, 2007). Tannins are considered nutritionally undesirable because they precipitate proteins, inhibit digestive enzymes and affect the utilization of vitamins and minerals (Awalet al, 1991). However, many tannin molecules have been reported to reduce the mutagenicity of a number of compounds and it all depends on the concentration at which it is used or consumed. To avoid these problems, it is recommended that during the preparation of extracts from these by-products, acidic and/or alkaline hydrolysis are recommended in order to inactivate these compounds (Rufino et al, 2010).

Fruit production, trade and consumption have increased significantly on the domestic and international markets due to their attractive sensory properties and a growing recognition of its nutritional and therapeutic value (Samadderet al, 1990). In many cases the raw fruit is not consumed directly by humans, but first undergoes processing to separate the desired value product from other constituents of the plant tissue. Like tropical crops such as jackfruit, pineapple, papaya and mango are typically valued for their fruit. Processing of these crops typically involves separating the valuable fruit part from byproducts such as skin and seeds (Aguilar et al, 2010). The mass of by-products obtained as a result of processing tropical exotic crops may approach or even exceed that of the corresponding valuable product, affecting the economics of growing tropical exotic crops (Miljkoet al, 2002).

The antimicrobial power of seeds and herb extracts has been recognized for centuries and mainly used as natural medicine. However, the trends in using these compounds as food preservatives is increasing now days (Ayalazalaet $a l, 2011)$. In addition, plants produce a wide range of volatile compounds, some of which are important for flavour quality factors in fruits, vegetables, spices, and herbs. Ever since, natural colours from spices and herbs as well as fruits and vegetables have been part of the everyday diet of humans (Soepadmoet al, 1992). It is well known that agro industrial by-products are rich in dietary fibres (DF). The DF additive provides economic benefits to the food, cosmetic and pharmaceutical industries (Ajilaet al, 2010).

Apart from the well-known health effects, dietary fibre shows some functional properties as food additives, such as water-holding capacity, swelling capacity, increasing viscosity or gel formation, which are essential in formulating certain food products (Azad et al, 1990). On the other hand, foods are perishable products as a cause of their intrinsic characteristics. Microbial growth, sensorial attribute decay and loss of nutrients are amongst the major causes that compromise the quality and safety of food 
produce (Janevskaet al, 2010). Chemical synthetic additives can reduce food decay but consumers are concerned about chemical residues in the products (Ayalaet al, 2011). Regarding the food safety issues, one of the major emerging technologies is the application of natural additives. We have to consider that the high content of bioactive compounds present in fruit byproducts can be used as natural food additives. If this approach is realized, it would be feasible to fulfil the requirements of consumers for natural and preserved healthy food. In addition, the full utilization of fruits could lead the industry to a lower-waste agribusiness and increasing industrial profitability.

Several potential uses can be considered for fruit and vegetable by-products, one of the majors can be as food additives (antimicrobials, antioxidants, colorants, flavouringsand thickener agents) (Arya et al, 2011). As anti-browning additives fruit and vegetables by-products are sources of a great variety of antioxidants, and their particular properties may be useful in maintaining food quality avoiding enzymatic browning in fruits (Singh et al, 2001). The enzymatic browning caused by polyphenol oxidase (PPO) is a major detrimental factor of the quality of fresh-cut fruits and vegetables (Sharmanet al, 2000). To avoid this problem, several additives have been applied mainly by dipping, spraying or vacuum impregnation. Antioxidants from fruit and vegetables by-products may be grouped in accordance to their mode of action, i.e. as acidulants, reducing and/or chelating agents and enzyme inhibitors. Therefore, their beneficial effects may differ among treated product and matrix applied (Aykroyd et al, 1966).Considering that peels and seeds of most exotic fruits are not consumed and rarely approached, the high number of bioactive compounds presented in these nonedible parts could be used for different purposes in the food industry such as enrichment or development of new products.

Okra (Abelmoschus esculentus Lam.) is an economically important, tall growing vegetable crop grown in tropical parts of the world. In India, it ranks number one in its consumption but its original home is Sudan and Ethiopia. It is cultivated throughout the tropical and warm temperate regions of the world for its green edible fibrous fruit and pods containing round, white seeds as well as for its ornamental value (Gunasenaet al, 1966). It is an oligo purpose crop, but it is usually consumed in a variety of ways. Okra plays an important role in the human diet by supplying fats, proteins, carbohydrates, minerals and vitamins. Moreover, its mucilage is suitable for certain medical and industrial applications. The mature okra seeds are a good source of oil and protein. They are rich in unsaturated fatty acids such as linoleic acid, which is essential for human nutrition. Okra seeds are popular due to their high fibre, vitamin-C and folate content
(Glacodvinet al, 2016). It also contains antioxidant properties. The seeds are known to be rich in high quality protein especially with regards to its content of amino acids relative to other plant protein source. Okra seeds do not only contain nutritionally important bio-compounds but are also sources of other Phyto compounds which at certain critical levels are significant anti-nutritional effects (Jacob et al, 2015). The seeds are inexpensive and widely distributed. Theses seeds can be used as an anti-diabetic and is beneficial in chronic or acute eczema.

Jackfruit (Artocarpusheterophyllus Lam.) is a popular food crop that is widely grown in Bangladesh and other tropical areas. Jackfruit seeds are light brown to brown, rounded, $2-3 \mathrm{~cm}(0.8-1.2 \mathrm{in})$ in length by $1-1.5 \mathrm{~cm}(0.4-0.6 \mathrm{in})$ in diameter, and enclosed in a thin, whitish membrane (Dang et al, 2014). Up to 500 seeds can be found in each fruit. As jackfruit is highly seasonal and seeds have shorter shelf life, hence go waste during the seasonal glut. Therefore, the seeds can be stored up to a month in cool, humid conditions. They can be eaten in boiled or roasted form. Thus, the jackfruit seeds are not only rich in proteins, starch and dietary fibers but can also be regarded as an abundant yet cheap source of the nutrients. Lectin, a class of glycoproteins found in jackfruit seed, possess an antibacterial, anti-fungal and anti-carcinogenic properties (Adekunle et al, 2008). Jackfruit contains both water and fat-soluble vitamins along with minerals like vitamin A, vitamin $\mathrm{C}$, thiamine, riboflavin, calcium, potassium, iron, sodium, zinc and niacin among many other nutrients. Jackfruit has a low caloric content. $100 \mathrm{~g}$ of jackfruit only contains 95 calories. Jackfruit is a rich source of potassium with $303 \mathrm{mg}$ found in $100 \mathrm{~g}$ of jackfruit (Chandrasekharappaet al, 1989). Studies show that food rich in potassium helps to lower blood pressure. Jackfruit contains phytonutrients: lignin's, isoflavones and saponins that have health benefits that are wide ranging. These phytonutrients have anticancer, antihypertensive, antiulcer and antiaging properties. The phytonutrients found in jackfruit, therefore, can prevent forming of cancer cells in the body, can lower blood pressure, can fight against stomach ulcers, and can slow down the degeneration of cells that make the skin look young and vitae (Yantyet al, 2007). Jackfruit also contains niacin which is necessary for energy metabolism, nerve function, and the synthesis of certain hormones (Rababahet al, 2006).

\section{OBJECTIVES}

* To estimate Nutrients elements of the samples (okra seed flour, jackfruit seed flour and whole wheat flour)

* To prepare composite flour

* To determine Functional properties and Mineral composition of Best Composite flour 
* To prepare cookies from the selected composite flour and check their Physical properties

- To assess the acceptability of the prepared cookies by Organoleptic Evaluation

\section{METHODOLOGY}

Methodologies inquire into potentialities and limitation of some technique or other it is a plan or procedure for carrying out strategies for obtaining valid information.

Methodology of the study was divided into 5 phases: PHASE I

Analysis of Chemical properties of Okra seed flour, Jackfruit seed flour and Whole wheat flour

This was the primary phase of our present study. After collecting the seeds and preparing them into flour, the proximate composition of the three flours i.e okra seed flour, jackfruit seed flour and wheat flour were estimated individually. The proximate composition of the flour includes the moisture content $(\%)$, fat (\%), crude fibre (\%), ash $(\%)$, protein $(\%)$ and carbohydrates $(\%)$.

\section{PHASE II}

\section{Standardization of Composite flour}

In this, random selection of flour variables were done and were divided into different ratios like Okra seed flour, whole wheat flour and jackfruit seed flour $(5: 85: 10)$. Total 16 variables were studied and for each variable, the proximate composition was calculated. The results of all 16 variable flours were compared and the best composite flour was selected according to the nutrient composition.

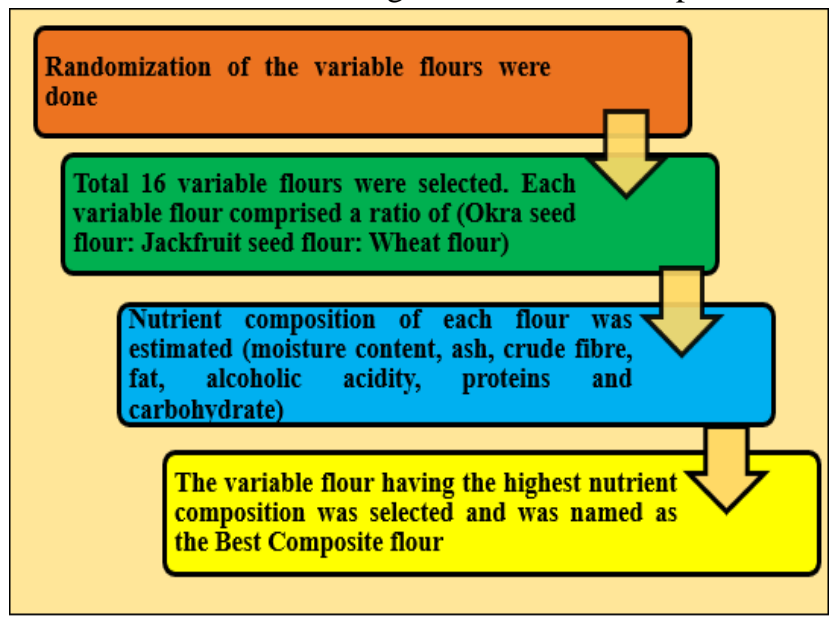

\section{Phase III}

\section{Best Flour According To Nutritional Quality}

The third phase of our present study was to find the Functional properties and Mineral analysis of the best composite flour. For the estimation of functional properties, I did the test of Bulk density (\%), Oil absorption capacity (\%) and Water absorption capacity (\%) to know the bulk and consistency of the composite flour. For mineral analysis, the test of Iron $(\mathrm{mg} / 100 \mathrm{~g})$, Calcuim (mg/100g), Zinc (mg/100g) and Potassium $(\mathrm{mg} / 100 \mathrm{~g})$ were done.

PHASE IV
Preparation of product (Cookies) and estimate Physical properties

In this phase, product was developed i.e. cookies and sensory evaluation of the product was done. Sensory evaluation of the developed food product was carried out using Triangular test for selection of the panel and for judging the formulated products, 9-point Hedonic rating scale with various attributed was conducted. There was Standard (S) and its four variation were made by incorporating okra seed flour, jackfruit seed flour and wheat flour with the amount 5\%,10\%,15\% and 20\% assigned as Sample A1, Sample A2, Sample A3 and Sample A4 respectively. After completing the sensory evaluation, the physical properties of the most acceptable product was carried out. In the physical properties, we estimated the swell power (\%), foaming capacity (\%), protein solubility (\%), oil and water absorption capacity (\%) of the product (cookies).

\section{PHASE V}

\section{Statistical analyis and Report writing}

This was the last phase of our present study. In this phase, we did statistical calculations i.e. estimation of mean, standard deviation and student's t-test. After the statistical analysis, report writing of our present study was done.

\section{Collection of Okra \& Jackfruit Seeds}

The seeds were collected from the local market of Kashmere gate district New Delhi., India during the late rainy season in the month of July-September.

\section{Preparation of Flour}

Okra and Jackfruit pods were washed, cut into slices and the seeds were extracted, washed, drained and dried at temperature of $60^{\circ} \mathrm{C}$ for 4 hours. The dried seeds were milled and sieved through $0.45 \mathrm{~mm}$ mesh sieve. The seed flour obtained were then sealed in a cellophane bag and stored thoroughly at room temperature, for further testing and incorporation in food products.

\section{RESULTS AND DISCUSSION}

Oncethe study has been conducted the next step involved the recording of results. Varied data was collected with the help of various methods in order to accomplish the study (Akuboor et al, 2003).

The purpose of any report is the dissemination of knowlegde and broadcasting the generation to ensure their widest use. The true and objective recording of the result is of paramount importance. It is the final step of a research endeavor to come up to a logical conclusion. Result of the research, thus constitute the final step, through which answer to the questions are sought.

Commencing with the collection of seeds (Artocarpus heterophyllum Lam.) and (Abelmoschus esculentus Lam.) and preparation of powder. This project was an attempt to assess the nutriotional, functional and mineral properties of okra seed flour, jackfruit seed flour and wheat flour. 
Further the study includes product development (Cookies) from the seeds powder and assessing their acceptability through 9-point hedonic scale and the most acceptable product to be further tested for the physical properties. At the end, statistical analysis and report writing was done.

The results of the study have been enumerated and disussed under the following heads:

1.1 Proximate composition

1.2 Nutrient composition of all Composite flour

1.3 Functional properties

1.4 Mineral analysis

1.5 Product development

1.6 Sensory evaluation

1.7 Physical parameters

Table 1.1. Proximate composition of Okra seed flour, Jackfruit seed flour and Wheat flour

\begin{tabular}{|l|l|l|l|}
\hline Proximate Analysis & $\begin{array}{l}\text { Okra seed } \\
\text { flour }\end{array}$ & $\begin{array}{l}\text { Jackfruit seed } \\
\text { flour }\end{array}$ & Wheat flou \\
\hline Moisture Content (g/100g) & $7.70 \pm 0.07$ & $9.08 \pm 0.6$ & $10.33 \pm 0.45$ \\
\hline Fat $(\mathrm{g} / \mathbf{1 0 0 g})$ & $3.62 \pm 0.3$ & $4.63 \pm 0.3$ & $2.33 \pm 0.1$ \\
\hline Crude Fibre (g/100g) & $5.64 \pm 0.4$ & $7.80 \pm 0.42$ & $3.90 \pm 0.1$ \\
\hline Ash Content (g/100g) & $6.61 \pm 0.4$ & $5.34 \pm 0.07$ & $2.12 \pm 0.3$ \\
\hline Protein (g/100g) & $5.99 \pm 0.4$ & $8.12 \pm 0.43$ & $11.97 \pm 0.6$ \\
\hline Carbohydrate (g/100g) & $65.01 \pm 0.23$ & $71.47 \pm 0.56$ & $77.35 \pm 0.51$ \\
\hline
\end{tabular}

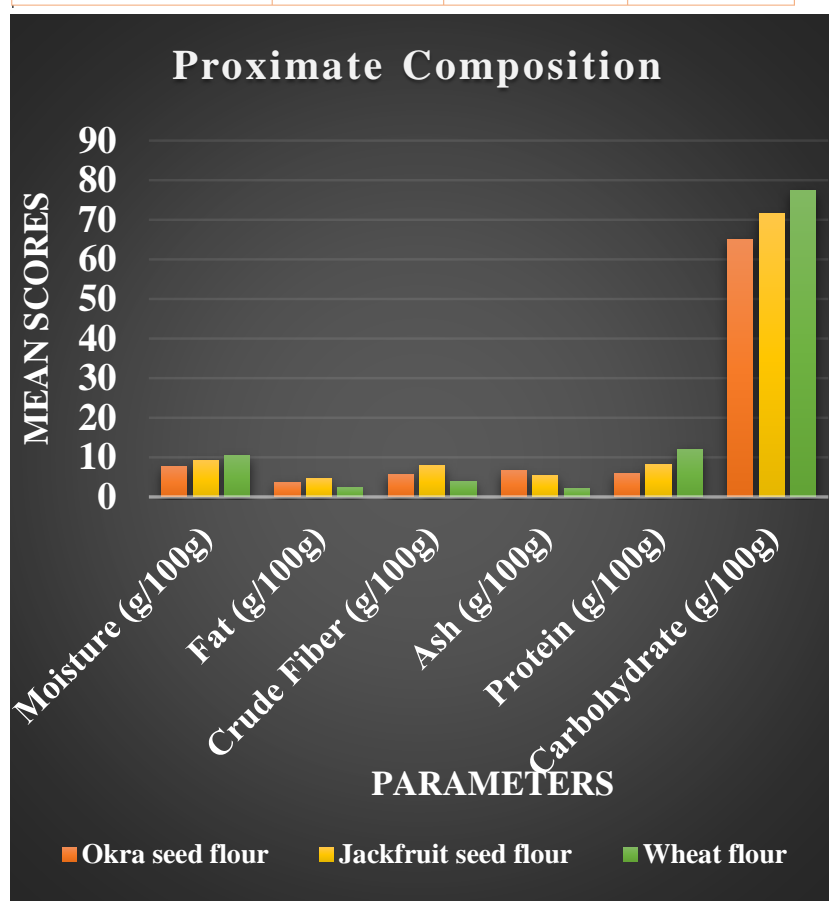

Fig.1.1: Proximate composition of Okra seed flour, Jackfruit seed flour and Wheat flour

\section{DISCUSSION}

As reported in the study of (Lakshiminarayanaet al, 2014), the moisture content of okra seed flour, jackfruit seed flour and wheat flour were $9.2 \pm 0.01,8.64 \pm 0.1$ and $12.56 \pm 0.05$. Low moisture content enhances the shelf life of a food product. Fat content was $3.62 \pm 0.3 .4 .63 \pm 0.3$ and $4.01 \pm 0.3$. Crude fiber was $3.01 \pm 0.01,4.60 \pm 0.22$ and $4.02 \pm 0.1$. The ash content was $5.33 \pm 0.2,5.1 \pm 0.4$ and $3.45 \pm 0.1$. The presence of protein is $6.56 \pm 0.2,5.01 \pm 0.1$ and $8.12 \pm 0.1$. Carbohydrate in the flour was $56.51 \pm 0.1,83.07 \pm 0.5$ and $73.15 \pm 0.2$. This suggests that the product can be good source of crude fiber and protein. Crude fiber is the residue that remain after a food sample has been subjected to treatment by acid and then by alkali under standard condition.it cleanses the digestive tract, by removing the potential carcinogens from the body and prevents the intake of excess starchy food. Jackfruit has been recognized as an excellent source of fiber, which is an important consideration for people who suffer from elevated cholesterol levels and in helping to cleanse the colon.

Table No. 1.2 Nutrient composition of all composite flour

\begin{tabular}{|c|c|c|c|c|c|c|c|c|c|c|}
\hline & \multicolumn{3}{|c|}{$\begin{array}{l}\text { Composite Mixed } \\
\text { Flour }\end{array}$} & \multicolumn{7}{|c|}{ Nutrients } \\
\hline S. No & 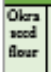 & $\begin{array}{l}\text { Whest } \\
\text { fleur }\end{array}$ & 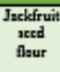 & 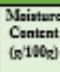 & 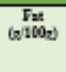 & 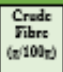 & 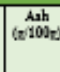 & 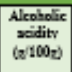 & 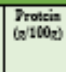 & 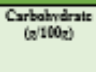 \\
\hline 1. & 10 & 50 & 40 & 9 & 15.76 & 3.5 & $1.0 \%$ & 1.12 & 2,84 & 66.91 \\
\hline 2. & 5 & 35 & 10 & 9 & 15.62 & 2.1 & 4.9 & 1.50 & 3.6 & 64.68 \\
\hline 3. & 7.5 & 525 & 45 & 95 & 1554 & 1.9 & 405 & $a, 5$ & 241 & 65.71 \\
\hline 4 & 6.25 & 76.25 & 17.5 & 95 & 17.19 & 3.3 & 204 & 2.24 & 227 & 64811 \\
\hline 5. & 5 & 55 & 40 & & 1607 & 2.7 & 405 & 1.83 & 3.12 & 66.18 \\
\hline 6. & 10 & 50 & 40 & 6.5 & 1923 & 3.3 & 302 & 210 & $2 \pi$ & की 13 \\
\hline 7. & 10 & 60 & 30 & 10 & 17.79 & 1.7 & 301 & 0.56 & 298 & 64.51 \\
\hline 8. & 5 & 85 & 10 & 10 & 17.75 & 20 & 246 & a47 & 1.1 .5 & 6691 \\
\hline 9 & 5 & 65 & 35 & 85 & 16.78 & 3.2 & 204 & 2312 & 298 & 92.11 \\
\hline 10. & 7.5 & 525 & 40 & 10 & 17.79 & 20 & 286 & 1.45 & 1.1 .5 & 6691 \\
\hline II. & 10 & 70 & 20 & 10 & 1453 & 1.7 & 301 & 1.68 & 298 & 64.51 \\
\hline 12. & 10 & 80 & 10 & 85 & 28.77 & 28 & (1098 & 2212 & 2.6 & 70.62 \\
\hline 13. & 6.25 & 61.25 & 325 & 8.5 & 12.65 & 3.1 & 204 & ats & 1.99 & 92,7 \\
\hline 14. & 10 & 80 & 10 & 9 & 12.54 & 3.2 & 483 & 1.53 & 1.14 & (18)35 \\
\hline 15. & 10 & 65 & 25 & 7 & 16,05 & 2.7 & 405 & 201 & 3.12 & 66.18 \\
\hline 16. & 5 & 55 & 40 & 8.5 & 1452 & 28 & 1009 & 1.85 & 286 & 20.67 \\
\hline Mena & & & & 8.78125 & 164778 & 2.615 & 3.2525 & 1.53125 & 2 265068 & 6527375 \\
\hline SD & & & & 1.125 & 2 2स6\%? & 0.162376 & 130196 & 0.6734 & aबEDI & $3.11 \times 12$ \\
\hline
\end{tabular}

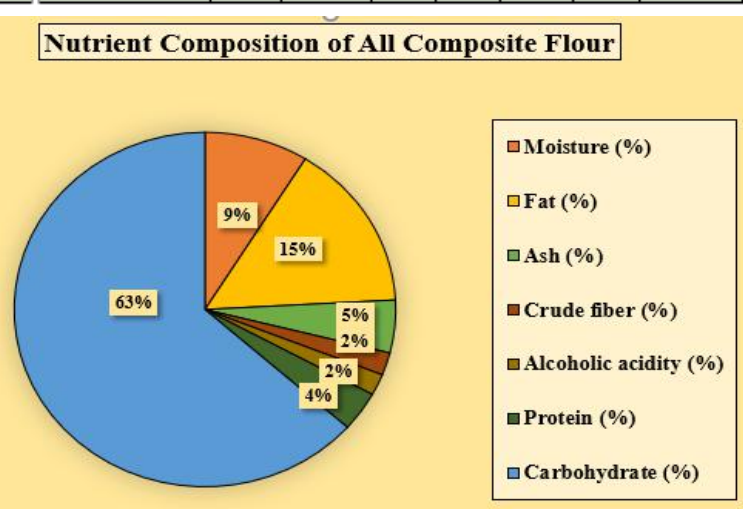

Fig.1.2: Nutrient composition of the best composite flour

\section{DISCUSSION}


Table 1.2 Represents the nutrient composition of all composite flours.Basically, it was done to find out the best composite flour according to the nutrient composition. Randomization of the variables were done during the ongoing process of our study. Total 16 variables were selected having different ratios of okra seed flour, jackfruit seed flour and whole wheat flour. After distributing the variable flours with the respective ratios, the nutrient composition for each variable flour was estimated. Under nutrient composition: moisture content, ash, crude fibre, fat, alcoholic acidity, proteins and carbohydrate test were done. The results were compared and it was seen that "Variable 2" which was a mixture of (Okra seed flour 5\% + Wheat flour $85 \%$ + Jackfruit seed flour 10\%) depicted a high percentage of the nutrients especially fat i.e. 15.62 $\mathrm{g} / 100 \mathrm{~g}$, ash i.e. $4.9 \mathrm{~g} / 100 \mathrm{~g}$,protein i.e. $3.69 \mathrm{~g} / 100 \mathrm{~g}$ and carbohydrate i.e. $64.68 \mathrm{~g} / 100 \mathrm{gas}$ compared to other variables which depicted a lesser value of nutrients. "Variable 2" was considered as the most suitable blending ratio for the production of cookies from okra seed flour, jackfruit seed flour and wheat flour. Thus "Variable 2" was selected as the Best Composite Flour and further testing were done on this flour.

Table 1.3. Functional properties of the best composite

\begin{tabular}{|c|c|}
\hline \multicolumn{2}{|c|}{ flour } \\
Functional Properties & Mean \pm SD \\
\hline Bulk Density $(\mathrm{g} / \mathrm{ml})$ & $\mathbf{0 . 9 5} \pm \mathbf{0 . 0 2}$ \\
\hline $\begin{array}{c}\text { Water Absorption } \\
\text { Capacity }(\mathbf{g} / \mathrm{ml})\end{array}$ & $\mathbf{1 . 6 8} \pm \mathbf{0 . 0 5 1}$ \\
\hline
\end{tabular}

\section{Oil Absorption Capacity} $(\mathrm{g} / \mathrm{ml})$

$1.81 \pm 0.057$

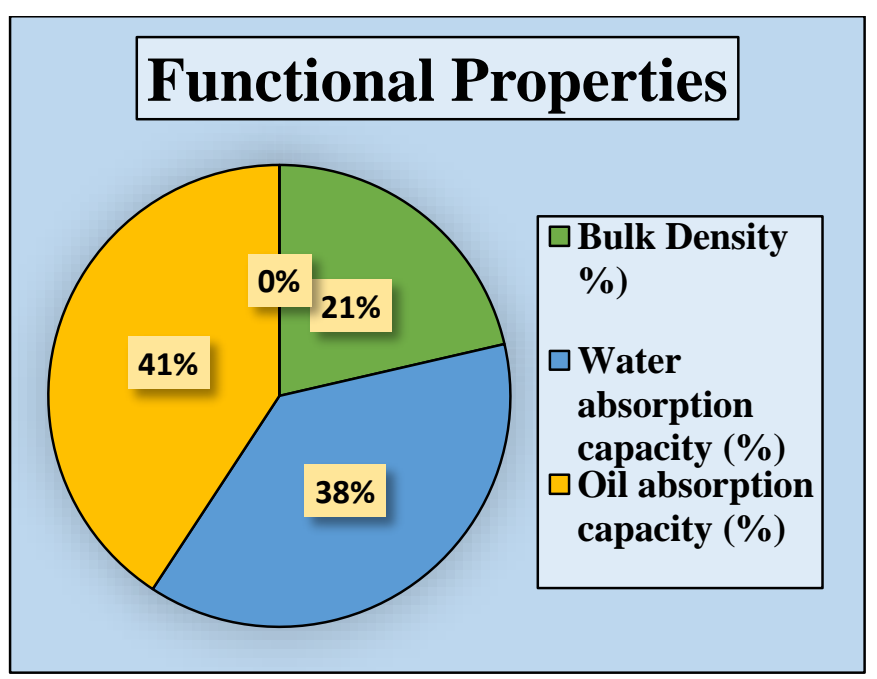

Fig.1.3: Functional properties of the best composite flour
Bulk density gives an indication of the relative volume of packaging material required. As reported by (Nibaet al, 2001 ), the bulk density of the flour was $1.24 \pm 0.1 \mathrm{~g} / \mathrm{g}$ which was higher than the results of our present study i.e. $0.95 \pm 0.02 \mathrm{~g} / \mathrm{g}$. Water absorption capacity is important in bulking and consistency of product as well as in baking applications. The result shows that the water absorption capacity of the composite flour was $1.10 \pm 0.1 \mathrm{~g} / \mathrm{g}$ which was lower than the findings of our study i.e. $1.68 \pm 0.051$ $\mathrm{g} / \mathrm{g}$. Oil absorption capacity is the ability of the flour protein to bind fat by capillary attraction. The oil absorption capacity of the flour was found to be $1.21 \pm 0.02 \mathrm{~g} / \mathrm{g}$ whereas the results of our finding shows the oil absorption capacity of the composite flour as shows that the oil absorption capacity of the flour was $1.81 \pm 0.057$ $\mathrm{g} / \mathrm{g}$. An increase in the oil absorption capacity could be attributed to the increase in the protein content of the composite flour. It is also important as oil acts as a flavour retainer and improves mouth feel.

Table No.1.4 Mineral composition of the best composite flour

\begin{tabular}{|c|c|}
\hline Mineral Content & Mean \pm SD \\
\hline Iron $(\mathrm{mg} / 100 \mathrm{~g})$ & $2.71 \pm 0.01$ \\
\hline Zinc $(\mathrm{mg} / 100 \mathrm{~g})$ & $1.61 \pm 0.02$ \\
\hline & \\
\hline Calcium $(\mathrm{mg} / 100 \mathrm{~g})$ & $3.49 \pm 0.02$ \\
\hline & \\
\hline Potassium $(\mathrm{mg} / 100 \mathrm{~g})$ & $1.46 \pm 0.02$ \\
\hline
\end{tabular}

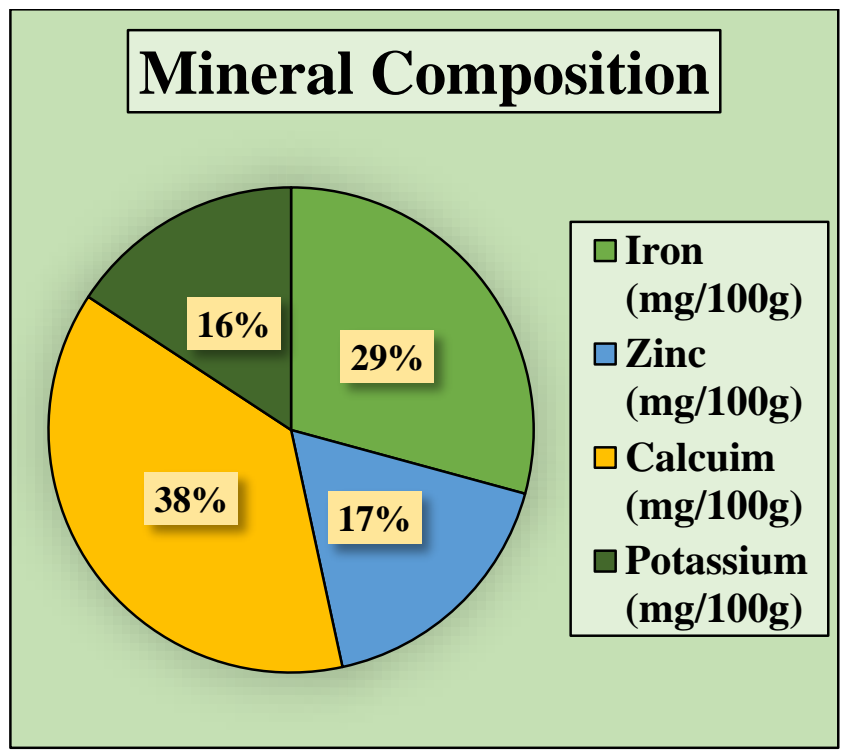

Figure 1.4 Mineral composition of the best composite flour

\section{DISCUSSION}

DISCUSSION 
As reported by (Abbah et al, 2015), the iron present in the composite flour was $1.52 \pm 0.07$ which was lower than the findings of our present study i.e. $2.71 \pm 0.1$. Iron has been reported as an essential trace metal and plays numerous biochemical roles in the body, including oxygen binding in hemoglobin and acting as an important cataltic center in enzyme. (Adeyeye et al, 1990). Zinc is an essential trace element that helps to stimulate the activity of different enzymes. In the study of (Abbah et al, 2015) the zinc content in the flour was $0.95 \pm 0.01$ which was lower than the findings of our study i.e. $1.61 \pm 0.02$. Calcuim is a major mineral sustaining strong bones and plays a part in muscles contraction and relaxation, blood clotting, synaptic transmission and absorption of vitamin B12 (Singh et al, 2003). The calcuim obtained from the flour was $3.01 \pm 0.01$. which was similar to the findings of our present study i.e. $3.49 \pm 0.02$. Potassium is an essential mineral micronutrient which is required for regulating fluid balance and controlling the electrical activity of the heart and muscles. The potassium content of our study was $1.46 \pm 0.02$ which was lower than the findings of (Adenkule et al, 2004) i.e. $2.82 \pm 0.07$. Calcuim, Iron and Zinc play a central role in the normal regulation of blood pressure. In particular, these elements have important inter-relation in the control arterial resistance.

\section{Product Development}

In the present study, a product was developed i.e. Cookies with the variations. There was a Standard (S) and its four variation were made by incorporating okra seed flour, jackfruit seed flour and wheat flour with the amount 5\%, $10 \%, 15 \%$ and $20 \%$ assigned as Sample A1, Sample A2, Sample A3 and Sample A4 respectively.

Table No. 1.5 Formulation of the best composite flour

\begin{tabular}{c|c|c|c|c} 
Sample & $\begin{array}{c}\text { Concen- } \\
\text { tration }\end{array}$ & $\begin{array}{c}\text { Okra } \\
\text { seed } \\
\text { flour }\end{array}$ & $\begin{array}{c}\text { Jackfruit } \\
\text { seed flour }\end{array}$ & $\begin{array}{c}\text { Whole } \\
\text { wheat } \\
\text { flour }\end{array}$ \\
\hline A1 & $\mathbf{5 \%}$ & $\mathbf{5 \%}$ & $\mathbf{1 0 \%}$ & $\mathbf{8 5 \%}$ \\
A2 & $\mathbf{1 0 \%}$ & $\mathbf{5 \%}$ & $\mathbf{1 0 \%}$ & $\mathbf{8 5 \%}$ \\
& & & & \\
A3 & $\mathbf{1 5 \%}$ & $\mathbf{5 \%}$ & $\mathbf{1 0 \%}$ & $\mathbf{8 5 \%}$ \\
& & & & \\
A4 & $\mathbf{2 0 \%}$ & $\mathbf{5 \%}$ & $\mathbf{1 0 \%}$ & $\mathbf{8 5 \%}$
\end{tabular}

Keywords:

S: Standard

A1: 5\% incorporation of okra seed flour, jackfruit seed flour and whole wheat flour
A2: $10 \%$ incorporation of okra seed flour, jackfruit seed flour and whole wheat flour

A3: $15 \%$ incorporation of okra seed flour, jackfruit seed flour and whole wheat flour

A4:20\% incorporation of okra seed flour, jackfruit seed flour and whole wheat flour
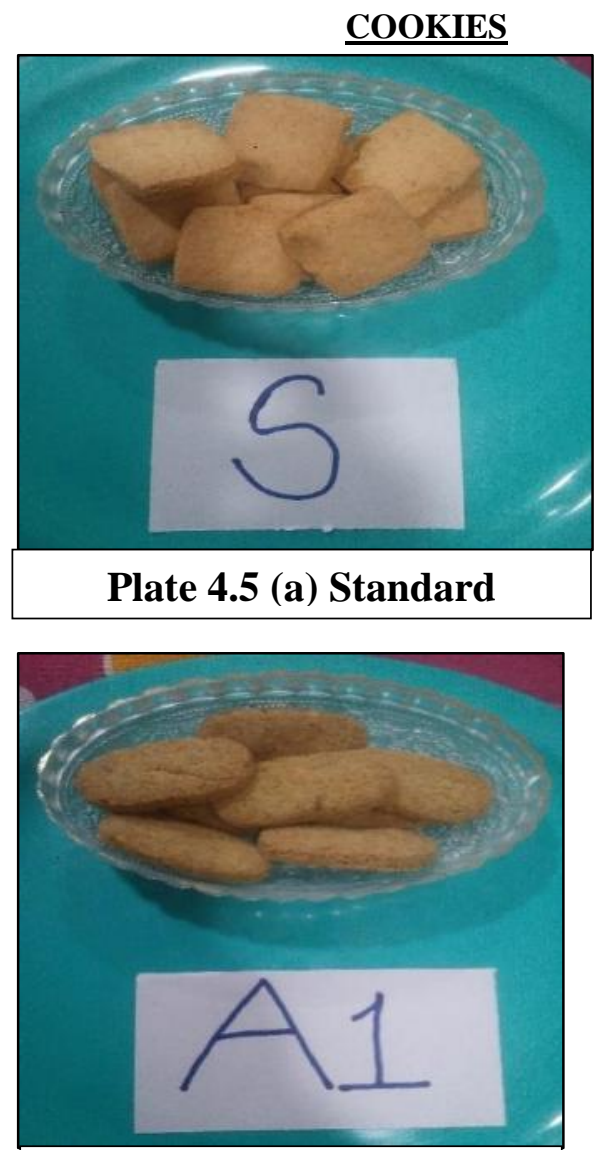

Plate 1.5 (b) $5 \%$ incorporation of best composite flour

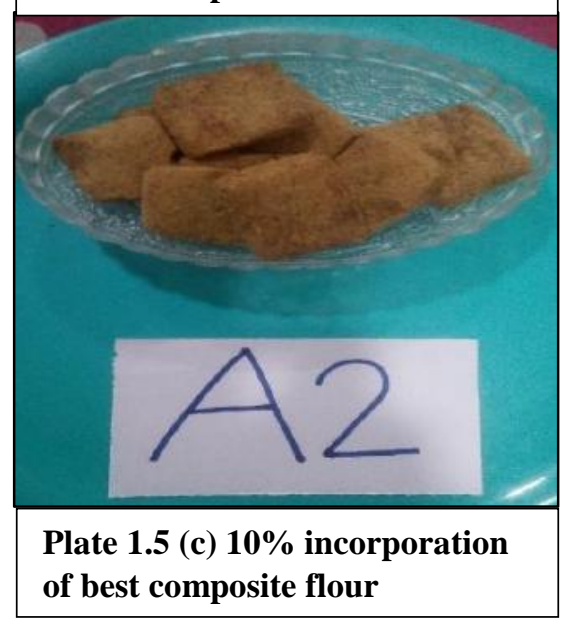




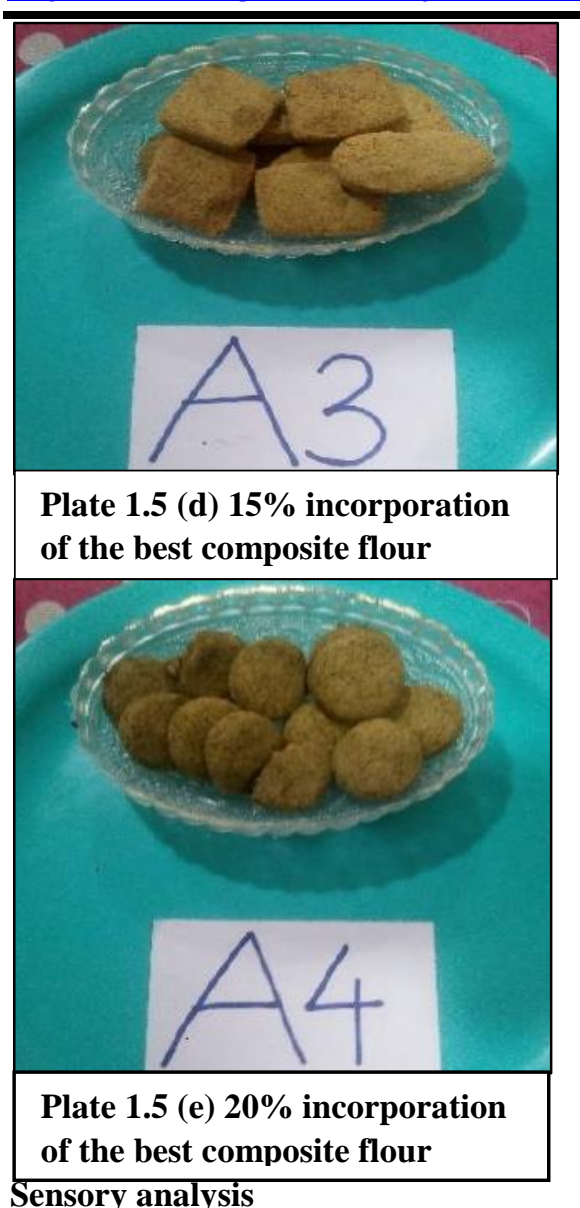

Sensory evaluation of the developed food product was carried out using Triangular test for selection of the panel and for judging the formulated products 9-point Hedonic rating scale with various attributed was conducted.

\section{Hedonic rating test}

Overall acceptability depends upon the concentration or amount of particular component, the nutrition and hidden attributes of a food and its palatability or sensory qualities. The newly developed products were graded by using 9 point hedonic scale, in which a score of 9 stood for 'like extremely' and score of 1 indicated 'dislike extremely'. The data obtained by hedonic scale was averaged by calculating the mean. The mean scores of different attributes were predicted below.

Table No. 1.6Sensory Evaluation of Cookies

\begin{tabular}{|c|c|c|c|c|c|}
\hline ATTRIBUTES & STANDARD & $\mathrm{Al}$ & A2 & $\mathrm{A} 3$ & $\mathrm{A4}$ \\
\hline COLOR & $8.75 \pm 0.44$ & $8.55 \pm 0.51^{\text {ns }}$ & $8.50 \pm 0.60^{\mathrm{ds}}$ & $8.10 \pm 0.72^{*}$ & $7.55 \pm 0.60^{\mathrm{ns}}$ \\
\hline APPEARANCE & $8.55 \pm 0.51$ & $8.45 \pm 0.51^{\text {ns }}$ & $8.36 \pm 0.77 \mathrm{us}$ & $7.70 \pm 0.80^{\mathrm{ns}}$ & $7.35 \pm 0.67 \mathrm{ps}$ \\
\hline FLAVOR & $8.7 \pm 0.47$ & $8.45 \pm 0.51^{\text {ns }}$ & $8.30 \pm 0.66^{*}$ & $7.90 \pm 0.64^{\mathrm{ns}}$ & $7.25 \pm 0.64^{\mathrm{ns}}$ \\
\hline TASTE & $8.75 \pm 0.44$ & $8.40 \pm 0.51^{\star}$ & $8.15 \pm 0.43^{\mathrm{ns}}$ & \begin{tabular}{|l}
$7.70 \pm 0.57 \mathrm{us}$ \\
\end{tabular} & $7.45 \pm 0.6^{\text {ns }}$ \\
\hline $\begin{array}{c}\text { OVERALL } \\
\text { ACCEPTABILITY }\end{array}$ & $8.81 \pm 0.41$ & $8.45 \pm 0.6^{*}$ & $8.40 \pm 0.5^{\star}$ & $7.65 \pm 0.49^{\mathrm{ns}}$ & $7.25 \pm 0.79 \mathrm{~ms}$ \\
\hline
\end{tabular}

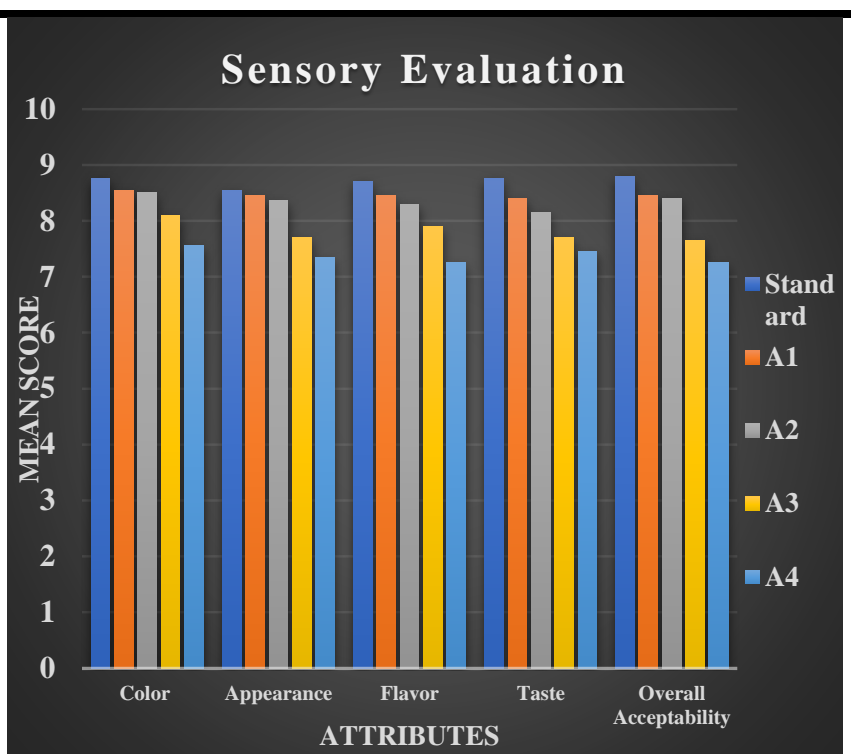

Fig.1.6: Sensory evaluation of Food product development of (Cookies)

\section{DISCUSSION}

As presented in table1.6. the cookies were prepared by the best composite flour which comprised of Okra seed flour, Jackfruit seed flour and Wheat flour in the ration of (5:10:85). The cookies were made by incorporating okra seed flour, jackfruit seed flour and wheat flour in four differenet concentration i.e. 5\% (Sample A), 10\% (Sample B), 15\% (Sample C) and 20\% (Sample D) respectively and were compared with the standard. The result states Mean \pm SD for all attributes (appearance, color, texture, taste and overall acceptability). The mean score secured for taste were ranging from $8.7 \pm 0.48$ to $8.4 \pm 0.5$ with the minimum score recorded for the sample D i.e. 7.2 \pm 0.6 with $20 \%$ level of incorporation. The mean score secured for appearance of cookies ranging from $8.7 \pm 0.4$ to $8.5 \pm 0.5$ with the minimum score recorded for the variant A4. Similarly in flavor and color the score ranges from $8.7 \pm 0.4$ to $8.4 \pm 0.5,8.7 \pm 0.4$ to $8.5 \pm 0.5$ with the minimum score recorded for Sample D. For overall acceptability mean score ranging from $8.8 \pm 0.4$ to $8.4 \pm 0.6$ with the maximum score recorded for the sample A i.e. $8.4 \pm 0.6$. Thus it can be conclued that the most acceptable food product is Sample A by the semi trained members.

Table No. 1.7 Physical properrties of the product developed (Cookies) with 5\% incorporation of the best composite flour

\begin{tabular}{|c|c|}
\hline Physical Parameters & Mean \pm SD \\
\hline Water absorption capacity & $3.74 \pm 0.01$ \\
\hline Oil absorption capacity $(\%)$ & $4.88 \pm 0.02$ \\
\hline Foaming capacity $(\%)$ & $\mathbf{4 . 0 1} \pm \mathbf{0 . 0 1}$ \\
\hline Swell Power $(\%)$ & $\mathbf{3 . 6 2} \pm \mathbf{0 . 0 2}$ \\
\hline Protein solubility $(\%)$ & $\mathbf{1 . 6 6} \pm \mathbf{0 . 0 1}$ \\
\hline
\end{tabular}




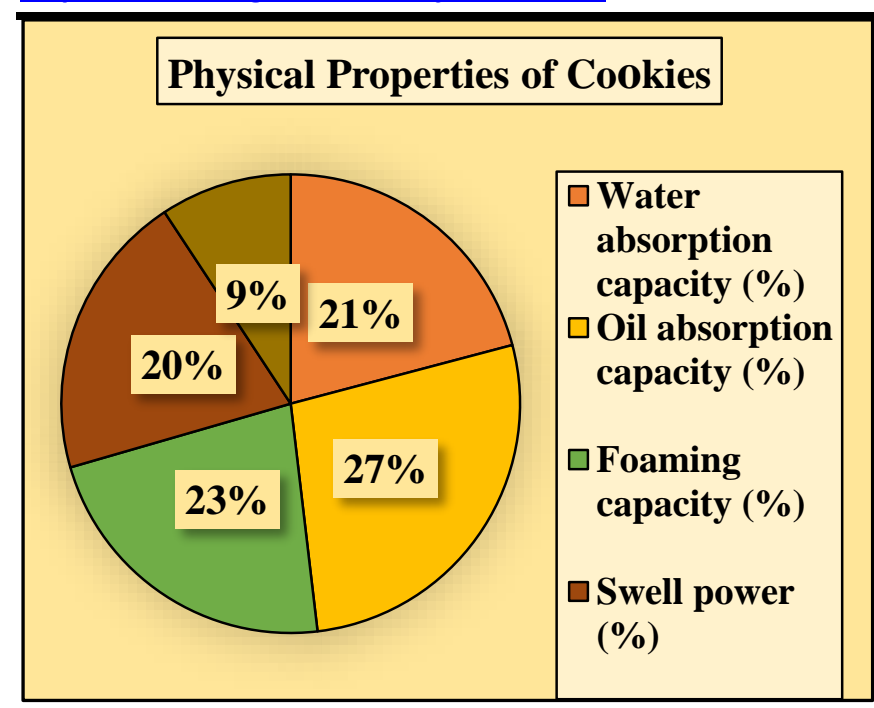

Fig.1.7: Physical Properties of the product developed (Cookies) with 5\% incorporation of the best composite flour

\section{DISCUSSION}

Water absorption capacity is important in bulking and consistency of product as well as in baking application as reported by (Nibaet al, 2001). The water absorption capacity of the flour was $3.74 \pm 0.01$ which was lower than the findings of (Nibaet al, 2001) i.e. 2.95 \pm 0.01 .The oil absorption capacity of the flour was high i.e. $4.88 \pm 0.02$. The oil absorption capacity obtained from the flour was similar to the findings of (Abu et al, 2014) i.e..4.53 \pm 0.01 .The Foaming capacity of the flour was found to be $4.01 \pm 0.01$ and it was similar to the findings of (Rababahet al, 2006) i.e. 3.96 \pm 0.02 . The composite flour has high surface viscosity property which means that the composite flour increases the hydrophobic nature of the protein matrix. Thus, the flour may have potential use as raw matter in the food industry.Swell power determines the extent to which a flour sample increases in volume when soaked in water in relation to its initial volume. The swelling power of the flour was $3.62 \pm 0.02$ which was higher than the findings of Okaka and Potter (1977) i.e..4.11 \pm 0.01 . The solubility of protein is considered as that proportion of nitrogen in a protein product which is in the soluble state under specific conditions. Solubility is the amount of protein in a sample that dissolves into solution. The percent solubility of the flour was $1.66 \pm 0.01$ while in the study of (Rababahet al, 2006) it was $0.96 \pm 0.01$.

\section{CONCLUSION}

The by-product seeds represent an important source of sugars, minerals, organic acid, dietary fibre and phenolics which have a wide range of action. These includes antiviral, antibacterial, cardio-protective and antimutagenic activities (Kumar et al, 1988). Fruit and vegetable seeds are thrown into the environment as agro waste which can be utilized as a source of anti-microbes (Bremneret al, 1996). Utilization of these by-products as a valuable source of natural food additives appears to be a good alternative toward mitigation of environmental problems and for further exploitation of food additives or supplements having high nutritional value and economically attractive. The transformation of these by products into a "product" with high added value makes it possible for the companies to reduce their cost of treatment and even to generate additional profits and thus to improve their competitiveness (Bobbioet al, 1978). Considering that seeds of most exotic fruits and vegetables are not consumed and rarely approached, the high number of bioactive compounds presented in these non-edible parts could be used for different purposes in the food industry such as enrichment or development of new products.

In conclusion, okra and jackfruit seeds are nutrient rich food that provides sufficient amount of nutrition needed for normal body function, maintenance and reproduction. The outcome of the study demonstrated that Artocarpusheterphyllus Lam.can serve as a good nutritional spring as they are a rich source of fibre, proteins, iron and zinc in comparison to Abelmoschus esculentus Lam. The presence of bio active compounds and phyto-nutrients are an assertion in the management of various ailments including wide-ranging cardiovascular and metabolic benefits, which can be readily incorporated into healthy diets. The functional properties present in Artocarpusheterphyllus Lam and Abelmoschus esculentus shows a vital role in preventing innumerable health disorders related to oxidative stress, diabetes and cancer.

As indicated in the results, the develop product-Cookies at $5 \%$ incorporation of the composite flour also showed a low glycaemic index which can be included in the diet for the management of diabetes more effectively. Thus, keeping in view of the above facts the present study was an attempt to estimate the proximate composition, functional properties, mineral properties and physical properties of the jackfruit seed flour, okra seed flour and wheat flour and development of commonly consumed food products by incorporating it.

In coming next generation, the importance of jackfruit seed and okra seed is going to increase because of their effectiveness, easy availability, low cost. Most of the people do not know their nutritional quality, health benefits and how to use and what to use. They are not utilized to its full potential. So, the basic aim of this study is to create data about the jackfruit and okra seed and its health benefits. A range of products will also be developed the popularize this seed among people and to ease its usage. These also lead to the conception of this project and the objectives designed under the study were successfully attained. 


\section{ACKNOWLEGEMENT}

Before I embark upon the presentation of this study it becomes my bounden duty to acknowledge all those people without whom this work would not have a reality first and foremost.

I thank "Waheguru jii" for the blessings he showered on me, which enabled me to do things correctly and inspired me to try again till the target was achieved. His endless mercies over me is the main key to my success. I feel this is a pleasant moment and great opportunity to thank all those learned souls who have helped me with their knowledge and experience to complete this project.

A formal statement of acknowledgement will hardly meet the end of justice in matter of experience deep sense of gratitude to my supervisor Ms. Parul Sharma, Assistant professor, Food Science \& Nutrition, Banasthali Vidyapith for her meticulous supervision and constant inspiration which helped me immensely in carrying out the study successfully.

No one would thrive in life without the blessings of their parents and family. I have no words to pay regard to my parents Mr. Shankar Sahai and Mrs. Savita Sahai who inculcated an urge of honesty and excellence to complete my dissertation. My special thanks to my lovely sister Soumya Sahai and brother Sreyas Sahai who have always supported me with their love and care.

I reveal my genuine thanks to my classmates and panellist for their co-operation.

\section{REFERENCES}

[1] Adekunle A.A. and oluwo O.A. the nutritive value of jackfruit seeds. American Journal of Food Technology. 2008; 3:141-146.

[2] Adeyeye, E.I. The effect of heat treatment on the invitro multi-enzyme digestibility of protein of six varieties of African yam bean flour. Food Chem., 1997; 60:509-512.

[3] Akobundu, E.N.T, Cherry, J.P. and Simmons, J.G. Chemical, functional and nutritional properties of egusi seed protein products. J. of Food Sci., 1982; 47:829-835.

[4] Akubor PI, Ukwuru MU. Functional properties and biscuit making potential of soybean and cassava flour blends. Plant Foods Hum Nutr 2003; 58:1-12.

[5] Amic, D, Davidovic-Amic, D, Besto, D, Trinajstic, N. (2003). Structure-Radical scavenging activity. Relationship of Flavonoids. Croatia Chemical Acta, 2003; 76(1):55- 61.

[6] Aminigo, E. R., Akingbala, J. O. Nutritive Composition and Sensory Properties of Ogi Fortified with Okra Seed Meal. J. Appl. Sci. Environ. Mgt., 2004; 8(2):23-28.
[7] AOAC (1990) Official Methods of Analysis. 15th ed. Association of Official Analytical Chemists. Washington, DC.

[8] Awal HMA, Gheyasuddin S. Biochemical parameters of jackfruit seed meal. Bangladesh J. Agril. Res. $1991 ; 16(1): 17-22$.

[9] Azad AK. Genetic diversity of jackfruit in Bangladesh and development of propagation methods. Ph.D. Thesis, Faulty of Engineering and Applied Sciences, Departmental Civil and Environmental Engineering, University of Southampton, 2010; 12:1180-188.

[10] Bhatia BS, Siddappa GS, Lal G. Composition and nutritive value of jackfruit. Indian J.Agri. Sci. 1955; 25:30-36.

[11]Block, G., Patterson, B., Subar, A. Fruits, vegetables and cancer prevention. A review of epidemiological evidence. Nutrition and Cancer, 1992; 18:1-29.

[12] Bobbio FO, El-Dash AA, Bobbio PA and Rodrigues L R. Isolation and characterization of the physicochemical properties of the starch of jackfruit seeds (Artocarpusheterorphyllus). Cereal Chem 1978; 55:505-511.

[13] Chandrasekharappa G. Nutritional quality of the blends of wheat and rice with bengal gram, red gram and black gram. Nutr Rep Int.1979; 18:401-410.

[14] Cheetham NWH and Tao L. Variation in crystalline type with amylose content in maize starch granules: An X-ray powder diffraction study. Carbohydrate Polymers 1998; 36:277-284.

[15] Claughton SM, Pearce RJ. Protein enrichment of sugar-snap cookies with sunflower protein isolates. J Food Sci. 1989; 54:354-356.

[16] Consultative Group on International Agricultural Research (CGIAR). Progress report by the CGIAR Task Force on Banana and Plantain Research. CGIAR Secretariat, World Bank, Washington, D.C., USA, 1993; 54:34-39.

[17] Consultative Group on International Agricultural Research (CGIAR). (1992). Future priorities and Strategies. CGIAR Technical Advisory Committee. TAC Secretariat FAO, Rome, Italy.

[18]Dang-I A.Y.., Pedevoah M.M., Tulasi E. Evalution of the effect of roasting on the physicochemical properties of Artocarpusheterophyllus seeds. International Journal of Applied Science and Technology. 2014; 4(4):257-262.

[19]Ejoh S.I and Ketiku O.A. Vitamin E content of traditionally processed products of two commonly consumed oilseeds in Nigeria. J. Nutr. Food Sci. 2013; 3(2):120-125.

[20]FAO (2009) Food and Agriculture Organisation of the United Nations. Joint Meeting of the Fourth Session of the Sub-group on Bananas and the Fifth 
Session of the Sub-Group on Tropical Fruits held in Rome, 9 - 11th December 2009.

[21] Ferguson E.L. Gibson RS, Lilian TU, Berry N \&Ounpuu S. Phytate, zinc and calcium content of 30 East Africa foods and their calculated phytate: Zn, Ca: phytate and [Ca] [phytate]/ [Zn] molar ratios. J Food Comp Analysis, 1988; 1:316-325.

[22] Gomez KA, Gomez AA. Statistical procedures for agricultural research. John Wiley \& Sons, Inc. New York., 1984; 71:44-46.

[23] Gupta SP. Statistical method. Sultan Chand and sons, New Delhi, 2006; 11:180-189.

[24] Hizukuri S, Takeda Y, Shitaozono T, Abe J, Ohtakara A, Takeda C, Saga C and Suzuki A. Structure and properties of water chestnut (Trapanatans L var bispinosa Makino) starch. Starch/Starke, 1988; 40:165-71.

[25] Hooda S, Jood S. Organoleptic and nutritional evaluation of wheat biscuits supplemented with untreated and treated fenugreek flour. Food Chem. 2005; 90:427-435.

[26] Hossain MK, Azizur R, Matior R, Jabbar M. Some low molecular weight compounds isolated and characterized from jackfruit (Artocarpusheterophyllus). J. Bang. Acad. Sci. 1990; 14:49-56.

[27] Indrani S, Savithri GD, Venkateswara Rao G. Effect of defatted soy flour on the quality of buns. J Food Sci Technol. 1997; 34, 440-442.

[28] Iyer L, Singh U. Functional properties of wheat and chickpea composite flours. Food Australia 1997; 49:27-31.

[29] Jacob A.G., Etong D, Tijani A. Proximate, mineral and anti-nutritional compositions of okra (Abelmoschus esculentus Lam.) seeds. British Journal of Research. 2015; 2(5):142-151.

[30] Jones JB. Laboratory Guide for Conducting soil tests and plant analysis. CRC Press: Boca Raton, FL. 2001; 141:27-160.

[31] Kaur M, and Arora R. Antioxidant activity of Artocarpusheterophyllus seeds for their therapeutic potential. International journal of Research in Ayurveda \& Pharmacy. 2011; 2(4):1235-1238.

[32] Kihiphoom SC. Utilization of okra seed. Int..Food Res J. 2012; 19:1325-1335.

[33] Kinsella JE. Functional properties of proteins in foods. Crit Rev Food Sci Nutr 1976; 1(3): 219-280.

[34] Kumar S, Singh AB, Abidi AB, Upadhyay RG and Singh A. Proximate composition of jack fruit seeds. J Food Sci Techno 1988; 25, 308-309.

[35]Lester G. Okra nutritional quality and health functionality. 1997; 7(3):222-227.
[36] Mazurs E, Schoch TJ and Kite FE. Graphical analysis of the Brabender viscosity curves of various starches. Cereal Chem 1957; 34:141-52.

[37] Meloan CF and Pomeranz Y. Food Analysis Laboratory Experiments. AVI Publishing Company, Inc, Westport, Connecticut. 1973; 20:10-14.

[38] Mepba HD, Eboh L, Nwaojigwa SU. Chemical composition, functional and baking properties of wheat-plantain composite flours. AJFAND 2007; $7: 1-22$.

[39] Morton J. 1987. Jackfruit (Artocarpusheterophyllus). In: Fruits of warm climates. Julia, F., Morton, Miami, F.L. 2011; 27:90-93.

[40] Mustafa AI, Alwessali MS, SI-Busha OM, Al-Amia RH. Utilization of cowpea flour and protein isolate in bakery products. Cereals Food World. 1986; 31:756759.

[41] Narashimham P. Breadfruit and jackfruit. In: Nagy S, Shaw PE, Wardowski WF. (eds.). Fruits of Tropical and Subtropical Origin Composition, Properties and Uses. Florida: Florida Science Source, Inc. p. 1990; 216-259.

[42] Narayana K, Narasinga Rao MS. Functional properties of raw and heat processed winged bean flour. J Food Sci. 1982; 42:534-538.

[43] Niba LL, Bokanga M, Jackson FI, Schlimme DS, Li BW. Physicochemical properties and starch granular characteristics of flour from various Manihotesculenta(cassava), genotype. J Food Sci 2001; 67:1701-1705.

[44] Noratlo GD, Bertoldi MC, Krenek K, Talcoh SU. Anticarcinogenic effects of Polyphenols from okra from varieties. J of Agricultural and Food Chemistry. 2010; 58:4104-4114.

[45] Okaka JC, Potter NN. Functional and storage properties of cowpea-wheat flour blends in breadmaking. J Food Sci. 1977; 42:822-833.

[46] Oliver-Bever B. Medicinal Plants in Tropical West African, London. Cambridge University press. 1986; 23:134-138.

[47] Potter NN (1986). Food science, $4^{\text {th }}$ edn. Van Nostrand Reinhold, Inc.., New York. 2009; 63:21-27.

[48] Pacheco-Delahaye E, Maldonado R,Pérez E \& Schroeder M. Production and characterisation of unripe plantain (Musa paradisiacal L) flours. Intersciencia 2008; 33 (4): 290-296.

[49] Popenoe, W. Manual of Tropical and Subtropical Fruits. Hafner press. Div. of Macmillan Publishing Co. Inc. p. 1974; 12:413-414.

[50] Purseglove JW. Tropical Crops. Dicotyledons 2. Longmans. Green and Co. Ltd. London and Harlow. p. $1968 ; 377-390$.

[51] Rababah TM, Al-Mahasneh MA, Ereifej KI. Effect of chickpea, broad Bean, or isolated soy protein (ISP) 
additions on the physicochemical and sensory properties of biscuits. J Food Sci. 2006; 71:438-442.

[52] Rahman MA, Nahar N, Mian AJ and Mosihuzzaman M. Variation of carbohydrate composition of two forms of fruit from jack tree (Artocarpusheterophyllus L) with maturity and climatic conditions. Food Chem 1999; 65, 91-97.

[53]Ranganna S. Manual of Analysis of fruits and Vegetable Products. Tata McGraw Hill Publishing Co. Lid. New Delhi, p. 1979; 1-20.

[54] Samaddar HN. Jackfruit. In. Fruits, Tropical and Subtropical (lstedn). Naya Prakash. 206 Bidhan Sarani. Calcutta. India, p. 1990; 637-639.

[55] Singh A, Kumar $S$ and Singh IS. Functional properties of jack fruit seed flour. Lebensm - Will u Technol 1991; 24, 373-374.

[56] Sosulski FW and McCurdy AR. Functionality of flours, protein fractions and isolates from peas and faba bean. J Food Sci 1976; 52:1010-1014.

[57] Stone H, Sidel JL. Sensory evaluation practices: Academic Press, San Diego (2006).

[58] Subagio A. Characterization of hyacinth bean (Lablab purpureus L. sweet) seeds from Indonesia and their protein isolate. Food Chem. 2006; 95:6570.

[59] Timsina B, Kilingar N. Jackfruit seeds: A potential source for the isolation of bioactive compounds with anti-cancer activity. International $\mathrm{J}$ of Pharmavy and Pharmaceutical Sci. 2015; 7(3):89-95.

[60] Tsen CC, Peters EM, Schaffer T, Hoover WJ. High protein cookies. Effect of soy fortification and surfactants. Bakers Digest 1973; 47:34-37.

[61] Wagner, K.H., Albig, K. and Maicold, K.G. The effect of okra-based cookies on osmolarity. 1975; 12:45-49.

[62] William PC, Singh U. Nutritional quality and the evaluation of quality in breeding programmes. In: Saxena MC, Singh KB, editors. The chickpea. Wallingford: CAB International/ICARDA. 1987; 22:329-356.

[63] Woodood N, Abmad N, Wadood A. Effects of Abelmoschus esculentus Lam. On diabetes mellitus. Pak. J of Medical Research 2000; 39:142-145.

[64] Yadav BS, Sharma A, Yadav RB. Studies on effect of multiple heating/cooling cycles on the resistant starch formation in cereals, legumes and tubers. Int $\mathrm{J}$ Food Sc Nutr. 2009; 60(1):258-272.

[65]Zhu XM, Song JX, Haung Z, Cohu XM, Yu MJ, Zhongguo Y, Li-Xue B. Antiviral activity of Artocarpusheterphyllus Lam against herpes simplex virus type 2 in vitro study. 1993; 14:452-454. 